Agro-Science Journal of Tropical Agriculture, Food, Environment and Extension Volume 9 Number 2 May 2010 pp. 90 - 96

ISSN 1119-7455

\title{
JUVENILE MORPHOLOGICAL MARKERS FOR MALENESS IN FLUTED PUMPKIN (TELFAIRIA OCCIDENTALIS HOOK F.)
}

\author{
Chukwurah $^{1}$, N.F. and Uguru ${ }^{2}$, M.I. \\ ${ }^{1}$ National Biotechnology Development Agency P.M.B. 5118 Wuse, Abuja, Nigeria \\ ${ }^{2}$ Department of Crop Science, University of Nigeria, Nsukka, Nigeria
}

\begin{abstract}
Six hundred seeds extracted from nine pods of fluted pumpkin (Telfairia occidentalis Hook F.) were sown in the field in 2004 and 2005 to determine the juvenile morphological markers for maleness. The result showed a significant difference $(P<0.05)$ between the male and female fluted pumpkin with respect to days to tendril emergence. The mean number of days to tendril emergence for the males were 19 and 20 days after planting (DAP) while that of the females were 47 and 43 days after planting $(D A P)$ in 2004 and 2005 respectively. The females grew faster with fewer tendrils while the males were relatively slow in growth and more prolific in tendril production. The distribution of the male and female plants with respect to number of leaves from emergence to 6 weeks after planting appears to suggest that the female plants produce leaves more profusely than the male plants. The frequency distribution with respect to the length of vine showed skewness to the right in favour of the females indicating that the females grew faster thereby producing longer vines than the males. The early and profused production of tendrils are phenotypic markers that distinguish the male from the female plants at the early growth stage of fluted pumpkin. These indicators can therefore be used to identify and possibly cull male plants which have very poor market acceptability as a leafy vegetable.
\end{abstract}

Keywords: Morphological markers, Sex expression, Fluted pumpkin, Telfairia occidentalis

\section{INTRODUCTION}

Fluted pumpkin (Telfairia occidentalis Hook F.) is a leafy vegetable of great economic importance. It belongs to the family, cucurbitaceae and originated from tropical west Africa (Irvine 1969, Esiaba, 1983). It is a herbaceous perennial crop although it is cultivated as an annual crop especially under the traditional farming system in West Africa. Fluted pumpkin has a vigorous perennial vine growing up to $10 \mathrm{~m}$ or more in length under favourable conditions (Rice, 1986). It produces tendrils that support the vine. Fluted pumpkin is dioecious with male and female flowers borne on different plants (Asiegbu, 1985). (Uguru and Onovo, 2010) reported an XY system of sex chromosomes with homogametic $\mathrm{XX}$ female and heterogametic XY male in fluted pumpkin. Cross pollination in fluted pumpkin is undertaken by insects and after fertilization; the seeds produced are enclosed by young drupelike pods which usually contains male and female seeds.

Fluted pumpkin is grown mainly for the leaves which constitute an important component of the diet in many West African countries (Gill, 1988). Farmers harvest the leaves either for consumption or for sale. Large succulent leaves attract higher premium than the small and poor quality leaves. The female plants are endowed with large succulent leaves while the male plants produce leaves that are scrawny, small and less attractive. Farmers therefore prefer the females to the males. Unfortunately, it is very difficult to differentiate the males from the females until the plants begin to flower. At this stage of development, the male plants begin to show signs of senescence and leaf yield drops. Overcoming this agronomic problem has been a major challenge to fluted pumpkin farmers in tropical West Africa. Sex-linked chromosonal markers would help distinguish the female plants from the male plant at an early stage of their growth. These juvenile markers may not easily be identified by many fluted pumpkin growers for lack of basic training. Visible phenotypic traits will be better appreciated by this group of farmers. It is important to have information on morphological markers in fluted pumpkin as an early guide for farmers who are more interested in the female plants. This study was therefore initiated to identify the morphological markers for maleness in fluted pumpkin at the juvenile growth stage. 


\section{MATERIALS AND METHODS}

Two experiments were conducted at the teaching and research farm of the Department of Crop Science, Faculty of Agriculture, University of Nigeria, Nsukka in the rainy season of 2004 and 2005. Nsukka is located at latitude $06^{0} 52^{1} \mathrm{~N}$, Longitude $07^{0} 24^{1} \mathrm{E}$ and at altitude of $447 \mathrm{~m}$. It is in the derived savanna agro-ecological zone with vegetation predominantly of grass and interspersed trees. The rainfall is bimodal with an annual total of about $1,500 \mathrm{~mm}$. The relative humidity ranges from $70 \%$ to $80 \%$ while the ambient temperature ranges from $20^{\circ} \mathrm{C}$ to $30^{\circ} \mathrm{C}$ during the rainy season.

Nine fluted pumpkin pods obtained from the market were used for the experiments. In 2004, seeds were extracted pod by pod and kept separate. Each unit of seeds was placed on banana leaves and covered for one day to remove the pulp. Thereafter, the seeds were washed with water, dried, weighed and numbered with indelible ink. A total of six hundred (600) seeds were planted in fifty nursery baskets containing sawdust at a planting depth of $3 \mathrm{~cm}$. Each basket contained twelve seeds. The seedlings were transplanted sequentially in arithmetic order for proper monitoring of the individual plants. A land area of $40 \mathrm{~m} \mathrm{x} 15 \mathrm{~m}$ was marked out for the research. The field was ploughed, harrowed and ridged mechanically. Fifteen ridges measuring $40 \mathrm{~m}$ x 1 $\mathrm{m}$ each were used for the experiment, the planting distance was $1 \mathrm{~m}$ within the row. Each ridge contained forty (40) stands. The plots were weeded manually throughout the experimental period and compound fertilizer NPK 20:10:10 was applied broadcast. The experiment was repeated in the 2005 to validate the results of the first year. The same set of data was collected and analyzed as was done in 2004.

\section{Data Collection and Statistical Analysis}

Individual seed weights were measured before planting. Data on days to shoot and tendril emergence, length of main vine $(\mathrm{cm})$, girth of vine at the base $(\mathrm{mm})$, number of leaves and tendrils were collected. The length of vine $(\mathrm{cm})$, girth of main vine $(\mathrm{mm})$ and number of leaves and tendrils were obtained at 2, 4, and 6 weeks after planting (WAP). The length of main vine was measured with a tape; the girth was measured with micrometer screw gauge and the number of leaves and tendrils were obtained by counting. Statistical analysis to determine the means, standard deviation and frequency distribution of the population were done using SPSS computer package version 10.0 and t-test analysis was done according to Satterhwaite (1946).

\section{RESULTS}

The mean weights of the seeds that grew into male and female plants are presented in Table 1. There was no significant difference $(\mathrm{P}>0.05)$ between the weights of the male and female seeds. The mean weights for the male and female seeds in 2004 were $11.4 \mathrm{~g}$ and $11.3 \mathrm{~g}$ while those of 2005 were $10.8 \mathrm{~g}$ and $10.8 \mathrm{~g}$, respectively.

Table 1: Mean weight of seeds (g) before planting, days to seedling and tendril emergence and girth of main vine $(\mathbf{m m})$ at 2,4 and 6 week after planting in 2004 and 2005.

\begin{tabular}{|c|c|c|c|c|c|}
\hline 2004 & Mean & & t-cal & t-tab & P-value \\
\hline & Male & Female & & & \\
\hline Mean weight of seeds (g) & 11.4 & 11.3 & -0.91 & 1.65 & $P>0.05$ \\
\hline $\begin{array}{l}\text { Days to seedling } \\
\text { emergence }\end{array}$ & 7.8 & 7.6 & -0.56 & 1.65 & $\mathrm{P}>0.05$ \\
\hline Days to tendril & 19.0 & 46.7 & 36.7 & 1.65 & $\mathrm{P}<0.05$ \\
\hline emergence & 5.5 & 6.0 & 0.03 & 1.65 & $\mathrm{P}>0.05$ \\
\hline Grith of main vine at 2 & 5.9 & 6.5 & 0.04 & 1.65 & $\mathrm{P}>0.05$ \\
\hline WAP & 6.5 & 7.4 & 0.14 & 1.65 & $\mathrm{P}>0.05$ \\
\hline $\begin{array}{l}\text { Grith of main vine at } 4 \\
\text { WAP }\end{array}$ & & & & & \\
\hline Grith of main vine at 6 & & & & & \\
\hline WAP & & & & & \\
\hline 2005 & & & & & \\
\hline Mean weight of seeds (g) & 10.8 & 10.8 & -0.19 & 1.65 & $\mathrm{P}>0.05$ \\
\hline $\begin{array}{l}\text { Days to seedling } \\
\text { emergence }\end{array}$ & 8.4 & 8.4 & -2.38 & 1.65 & $\mathrm{P}>0.05$ \\
\hline Days to & 20.1 & 43.3 & 35.7 & 1.65 & $\mathrm{P}<0.05$ \\
\hline emergence & 5.2 & 6.0 & 0.7 & 1.65 & $\mathrm{P}>0.05$ \\
\hline Grith of main vine at 2 & 5.8 & 6.4 & 0.03 & 1.65 & $\mathrm{P}>0.05$ \\
\hline WAP & 6.1 & 6.9 & 0.08 & 1.65 & $\mathrm{P}>0.05$ \\
\hline Grith of main vine at 4 & & & & & \\
\hline Grith of main vine at 6 & & & & & \\
\hline WAP & & & & & \\
\hline
\end{tabular}

The mean number of days to shoot emergence for the male and female plants in 2004 were 7.8 and 7.6 while that of 2005 were 8.4 and 8.1 , respectively. Gender had no significant influence on weight of seeds and days to shoot emergence in both years. The mean number of days to tendril emergence of the male and female plants is also presented in Table 1. The frequency distribution of the male and female plants with respect to days to tendril emergence are presented in Figs 1a-d. In 2004, the number of days to tendril emergence in the male population ranged from 8.0 to 65.0 with a mean of 19.0 (Figure 1a). A standard deviation of 9.24 indicates that $95 \%$ of the males produced tendrils between 0.52 and 37.48 days after planting (DAP). In the female population, the number of days to tendril emergence ranged from 10.0 to 88.0 with a mean of 46.7 (Figure 1a). A standard deviation of 19.72 shows that $95 \%$ of the females produced tendrils between 7.26 and 86.14 DAP. In 2005 , the number of days to tendril emergence ranged from 10.0 to 70.0 days after planting in the male population with a mean of 20.1 DAP (Figure 1c). A standard deviation of 11.09 implies that $95 \%$ of the male population produced tendrils between 2.08 and 42.28 days after planting. In the female 
Chukwurah, N.F. and Uguru, M.I.

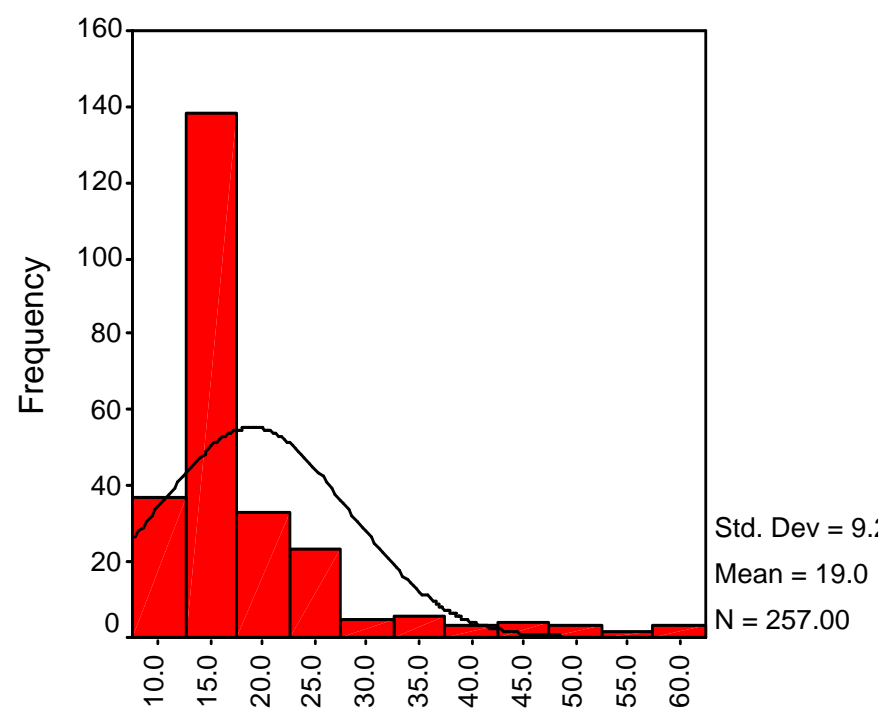

Days

Fig. 1a. Days to tendril emergence of males in 2004

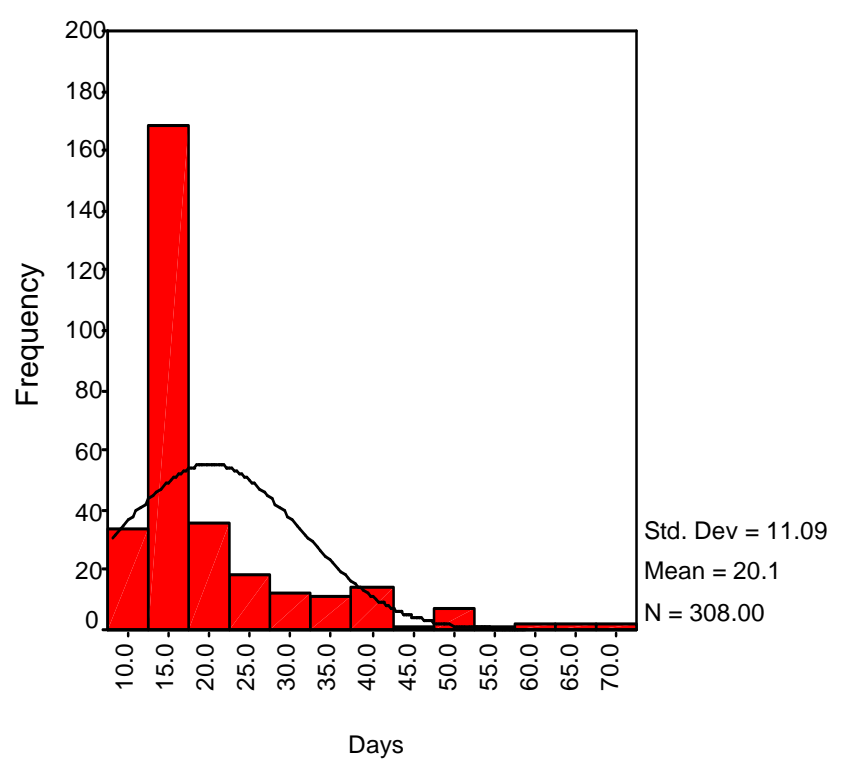

Fig. 1c. Days to tendril emergence of males in 2005

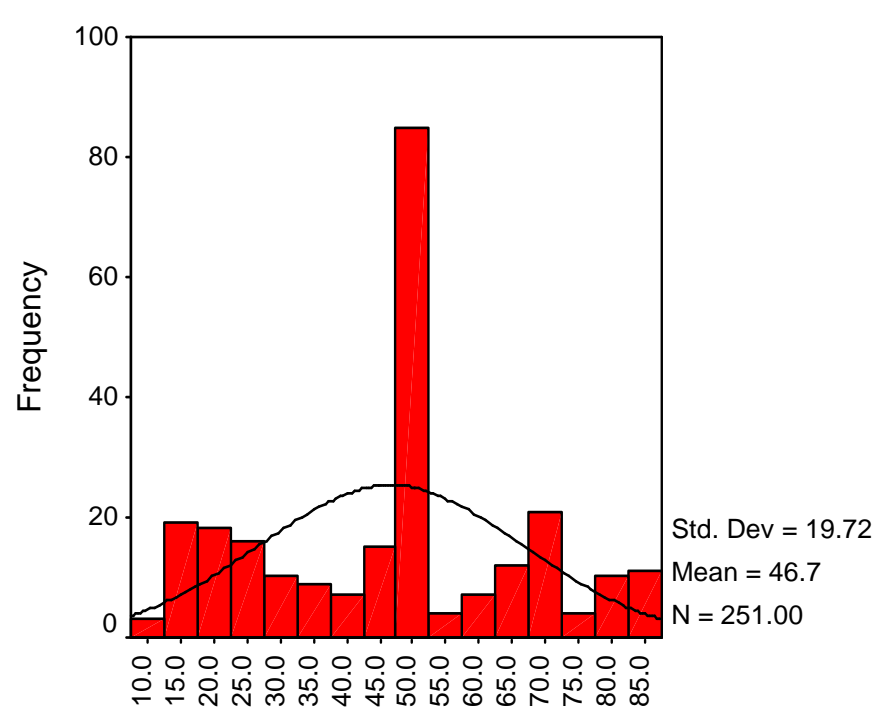

Days

Fig.1b. Days to tendril emergence of females in 2004

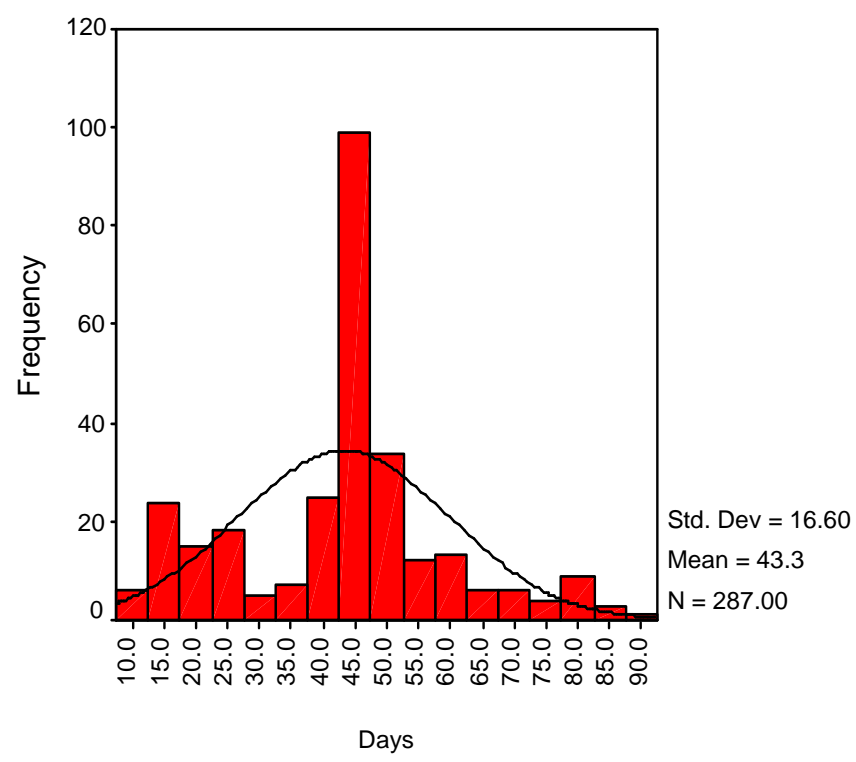

Fig. 1d. Days to tendril emergence of females in 2005

Figs (1a-d): Frequency distribution of male and female fluted pumpkin with respect to days to tendril emergence in 2004 and 2005 
population, the number of days to tendril emergence ranged from 12.0 to 95.0 DAP with a mean of 43.3 DAP (Figure 1d). A standard deviation of 16.60 indicates that $95 \%$ of the female population produced tendrils between 10.1 and 76.5 days after planting.

The length of vine was measured at 2 , 4 , and 6 weeks after planting. The frequency distribution of the population for length of vine at 2, 4, and 6 weeks after planting are presented in Table 2. At 2 WAP in 2004, the length of vine in the male population ranged from $4.0 \mathrm{~cm}$ to $20.0 \mathrm{~cm}$ with a mean of $8.8 \mathrm{~cm}$ (Table 2). A standard deviation of 2.41 indicates that $95 \%$ of the male plants produced vines with length between $3.98 \mathrm{~cm}$ and $13.62 \mathrm{~cm}$ per plant. In the female population, the length of vine at $2 \mathrm{WAP}$ ranged from $6.0 \mathrm{~cm}$ to $28.0 \mathrm{~cm}$ with a mean of $16.6 \mathrm{~cm}$ (Table 2). A standard deviation of 2.77 shows that $95 \%$ of the females had vine length with the range of $11.06 \mathrm{~cm}$ to $22.14 \mathrm{~cm}$. In 2005 , the length of vine in the male population at 2 WAP ranged from $4.0 \mathrm{~cm}$ to $21.0 \mathrm{~cm}$ with a mean of $9.4 \mathrm{~cm}$ (Table 2). A standard deviation of 2.89 implies that $95 \%$ of the male population were between $3.62 \mathrm{~cm}$ to $15.18 \mathrm{~cm}$. In the female population, the length of vine ranged from $8.0 \mathrm{~cm}$ to $30.0 \mathrm{~cm}$ with a mean of $17.7 \mathrm{~cm}$ at $2 \mathrm{WAP}$ (Table 2). A standard deviation of 2.90 indicates that $95 \%$ of the females have length of vine that fell within the range of $11.9 \mathrm{~cm}$ to $23.5 \mathrm{~cm}$.

At 4 WAP, the females had longer vine than the males (Table 2). The difference was significant $(\mathrm{P}<0.01)$. The frequency distribution of the population showed that the length of vine for the male plants ranged from $15.0 \mathrm{~cm}$ to $72.0 \mathrm{~cm}$ with a mean of 32.1 (Table 2). A standard deviation of 7.56 indicates that $95 \%$ of the male populations were between 16.98 to $47.22 \mathrm{~cm}$ in length. In the female population, the length of vine ranged from $20.0 \mathrm{~cm}$ to $102.0 \mathrm{~cm}$ with a mean of $74.2 \mathrm{~cm}$ (Table 2). A standard deviation of 15.07 shows that $95 \%$ of the female population have length of vine that fell within the range of 44.06 and $104.34 \mathrm{~cm}$. In 2005, the distribution of the plants with respect to length of vine in the male and female population were similar to the result obtained at 4 WAP in 2004.

The trend was consistent at 6 weeks after planting with mean vine length of $138.8 \mathrm{~cm}$ for the males and $191.6 \mathrm{~cm}$ for the females in 2004. In 2005, the female plants maintained the same tempo in the length of vine as in 2004 with the value of $191.7 \mathrm{~cm}$ at 6 weeks after planting in comparison with the value of $139.5 \mathrm{~cm}$ obtained from the male plants at 6 weeks after planting.

The number of leaves of the male and female fluted pumpkin obtained in 2004 and 2005 were measured at 2, 4, and 6 after planting (WAP). The results are presented in Table 3. In 2004, the number of leaves in the male population ranged from 2 , to 19 with a mean of 6.7 at 2 WAP (Table 3 ). A standard deviation of 2.11 shows that $95 \%$ of the male population have number of leaves that fell within the range of 2.48 to 10.92 . In the female population, the number of leaves ranged from 4 to 30 with a mean of 15.0 at 2 WAP in 2004 (Table 3). A

Table 2: Frequency distribution of the Male and Female Fluted pumpkin with respect to length of main vine at 2,4 and 6 weeks after planting.

\begin{tabular}{|c|c|c|c|c|c|c|c|c|c|c|c|c|c|c|c|}
\hline Wk & $\begin{array}{l}\text { Mid-class } \\
\text { Values }\end{array}$ & 2 & 6 & 9 & 12 & 15 & 18 & 21 & 24 & 27 & 30 & Range & Mean & SD & $\mathbf{N}$ \\
\hline \multirow{7}{*}{2} & 2004 & & & & & & & & & & & & & & \\
\hline & Male & 37 & 90 & 59 & 25 & 20 & 20 & 6 & 0 & 0 & 0 & $4.0-20.0$ & 8.8 & 2.41 & 257 \\
\hline & Female & 0 & 20 & 25 & 29 & 30 & 70 & 45 & 17 & 15 & 0 & $6.0-28.0$ & 16.6 & 2.77 & 251 \\
\hline & 2005 & & & & & & & & & & & & & & \\
\hline & Male & 41 & 72 & 85 & 60 & 20 & 18 & 12 & 0 & 0 & 0 & 4.021 .0 & 9.4 & 2.90 & 308 \\
\hline & Female & 0 & 0 & 24 & 37 & 40 & 95 & 52 & 20 & 12 & 7 & $8.0-30.0$ & 17.7 & 2.90 & 287 \\
\hline & $\begin{array}{l}\text { Mid-class } \\
\text { values }\end{array}$ & 15 & 30 & 45 & 60 & 75 & 90 & 105 & 120 & 135 & 150 & Range & Mean & SD & $\mathbf{N}$ \\
\hline \multirow{7}{*}{4} & 2004 & & & & & & & & & & & & & & \\
\hline & Male & 81 & 107 & 30 & 28 & 11 & 0 & 0 & 0 & 0 & 0 & $15.0-72.0$ & 32.1 & 7.56 & 257 \\
\hline & Female & 2 & 16 & 21 & 30 & 100 & 45 & 37 & 0 & 0 & 0 & $20.0-102.0$ & 74.2 & 15.07 & 251 \\
\hline & 2005 & & & & & & & & & & & & & & \\
\hline & Male & 63 & 135 & 60 & 50 & 0 & 0 & 0 & 0 & 0 & 0 & $15.0-60.0$ & 34.6 & 9.17 & 308 \\
\hline & Female & 3 & 13 & 25 & 57 & 75 & 64 & 30 & 20 & 0 & 0 & $20.0-118.0$ & 76.0 & 15.70 & 287 \\
\hline & $\begin{array}{l}\text { Mid-class } \\
\text { values }\end{array}$ & 27 & 54 & 81 & 108 & 135 & 162 & 189 & 216 & 243 & 270 & Range & Mean & SD & $\mathbf{N}$ \\
\hline \multirow{6}{*}{6} & 2004 & & & & & & & & & & & & & & \\
\hline & Male & 0 & 26 & 34 & 40 & 70 & 50 & 29 & 10 & 8 & 0 & $50.2-245.9$ & 138.8 & 21.85 & 257 \\
\hline & Female & 0 & 0 & 10 & 13 & 25 & 30 & 70 & 45 & 38 & 20 & $85.0-260.0$ & 191.6 & 26.48 & 251 \\
\hline & 2005 & & & & & & & & & & & & & & \\
\hline & Male & 0 & 15 & 25 & 40 & 142 & 32 & 21 & 19 & 14 & 0 & $47.5-244.0$ & 139.5 & 20.72 & 308 \\
\hline & Female & 0 & 0 & 12 & 17 & 21 & 36 & 90 & 45 & 38 & 28 & $95.7-261.0$ & 191.7 & 23.77 & 287 \\
\hline
\end{tabular}


Table 3: Frequency distribution of male and female fluted pumpkin with respect to number of leaves per plant at 2,4 and 6 weeks after planting.

\begin{tabular}{|c|c|c|c|c|c|c|c|c|c|c|c|c|c|c|c|}
\hline $\mathbf{W k}$ & $\begin{array}{l}\text { Mid-class } \\
\text { values }\end{array}$ & 3 & 6 & 9 & 12 & 15 & 18 & 21 & 24 & 27 & 30 & Range & Mean & SD & $\mathbf{N}$ \\
\hline \multirow{7}{*}{2} & 2004 & & & & & & & & & & & & & & \\
\hline & Male & 40 & 158 & 30 & 20 & 7 & 2 & 0 & 0 & 0 & 0 & $2-19$ & 6.7 & 2.11 & 257 \\
\hline & Female & 3 & 12 & 25 & 45 & 58 & 65 & 30 & 10 & 0 & 3 & $4-30$ & 15.0 & 3.89 & 251 \\
\hline & 2005 & & & & & & & & & & & & & & \\
\hline & Male & 26 & 135 & 100 & 30 & 11 & 4 & 0 & 2 & 0 & 0 & $4-24$ & 7.8 & 2.45 & 308 \\
\hline & Female & 0 & 24 & 34 & 30 & 51 & 60 & 42 & 30 & 16 & 0 & $6-27$ & 16.3 & 4.0 & 287 \\
\hline & $\begin{array}{l}\text { Mid-class } \\
\text { values } \\
\end{array}$ & 10 & 20 & 30 & 40 & 50 & 60 & 70 & 80 & 90 & 100 & Range & Mean & SD & $\mathbf{N}$ \\
\hline \multirow{7}{*}{4} & 2004 & & & & & & & & & & & & & & \\
\hline & Male & 57 & 160 & 30 & 10 & 0 & 0 & 0 & 0 & 0 & 0 & $10-38$ & 19.7 & 6.63 & 257 \\
\hline & Female & 0 & 36 & 21 & 43 & 77 & 35 & 20 & 11 & 8 & 0 & $17-90$ & 47.8 & 13.0 & 251 \\
\hline & 2005 & & & & & & & & & & & & & & \\
\hline & Male & 63 & 221 & 20 & 4 & 0 & 0 & 0 & 0 & 0 & 0 & $8-40$ & 18.8 & 6.08 & 308 \\
\hline & Female & 9 & 15 & 21 & 56 & 70 & 40 & 40 & 25 & 11 & 0 & $14-90$ & 52.0 & 15.0 & 287 \\
\hline & $\begin{array}{l}\text { Mid-class } \\
\text { values }\end{array}$ & 16 & 32 & 48 & 64 & 80 & 96 & 112 & 128 & 144 & 160 & Range & Mean & SD & $\mathbf{N}$ \\
\hline \multirow{6}{*}{6} & 2004 & & & & & & & & & & & & & & \\
\hline & Male & 0 & 42 & 70 & 80 & 27 & 20 & 12 & 6 & 0 & 0 & $28-120$ & 62.0 & 20.51 & 257 \\
\hline & Female & 0 & 0 & 7 & 17 & 32 & 65 & 58 & 39 & 28 & 5 & $50-155$ & 105.6 & 19.71 & 251 \\
\hline & 2005 & & & & & & & & & & & & & & \\
\hline & Male & 0 & 50 & 77 & 102 & 44 & 18 & 12 & 5 & 0 & 0 & $27-125$ & 61.8 & 20.40 & 308 \\
\hline & Female & 0 & 0 & 0 & 18 & 24 & 48 & 58 & 64 & 60 & 15 & $65-154$ & 116.4 & 57.67 & 287 \\
\hline
\end{tabular}

Table 4: Frequency distribution of male and female fluted pumpkin with respect to number of tendrils per plant at 2,4 and 6 weeks after planting.

\begin{tabular}{|c|c|c|c|c|c|c|c|c|c|c|c|c|c|c|c|}
\hline $\mathbf{W k}$ & $\begin{array}{l}\text { Mid-class } \\
\text { values }\end{array}$ & $\mathbf{0}$ & 2 & 4 & 6 & 8 & 10 & 12 & 14 & 16 & 18 & Range & Mean & SD & $\mathbf{N}$ \\
\hline \multirow{7}{*}{2} & 2004 & & & & & & & & & & & & & & \\
\hline & Male & 13 & 32 & 37 & 107 & 40 & 21 & 7 & 0 & 0 & 0 & $0-13$ & 5.7 & 2.18 & 257 \\
\hline & Female & 64 & 140 & 32 & 12 & 3 & 0 & 0 & 0 & 0 & 0 & $0-9$ & 2.0 & 1.78 & 251 \\
\hline & 2005 & & & & & & & & & & & & & & \\
\hline & Male & 25 & 69 & 70 & 73 & 34 & 17 & 12 & 8 & 0 & 0 & $0-15$ & 5.0 & 2.71 & 308 \\
\hline & Female & 88 & 128 & 38 & 20 & 8 & 5 & 0 & 0 & 0 & 0 & $0-10$ & 2.2 & 1.79 & 287 \\
\hline & $\begin{array}{l}\text { Mid-class } \\
\text { values }\end{array}$ & $\mathbf{0}$ & 4 & 8 & 12 & 16 & 20 & 24 & 28 & 32 & 36 & Range & Mean & SD & $\mathbf{N}$ \\
\hline \multirow{7}{*}{4} & 2004 & & & & & & & & & & & & & & \\
\hline & Male & 3 & 10 & 15 & 18 & 35 & 132 & 21 & 15 & 8 & 0 & $0-30$ & 18.5 & 5.29 & 257 \\
\hline & Female & 54 & 150 & 27 & 7 & 5 & 3 & 2 & 0 & 0 & 0 & $0-24$ & 4.3 & 3.29 & 251 \\
\hline & 2005 & & & & & & & & & & & & & & \\
\hline & Male & 0 & 15 & 21 & 60 & 118 & 42 & 32 & 20 & 0 & 0 & $2-27$ & 16.2 & 5.82 & 308 \\
\hline & Female & 65 & 172 & 27 & 12 & 7 & 4 & 0 & 0 & 0 & 0 & $0-20$ & 4.3 & 3.0 & 287 \\
\hline & $\begin{array}{l}\text { Mid-class } \\
\text { values }\end{array}$ & $\mathbf{0}$ & 8 & 16 & 24 & 32 & 40 & 48 & 56 & 64 & 72 & Range & Mean & SD & $\mathbf{N}$ \\
\hline \multirow{5}{*}{6} & Male & 0 & 2 & 6 & 9 & 12 & 23 & 130 & 32 & 43 & 0 & $8-67$ & 48.3 & 8.85 & 257 \\
\hline & Female & 18 & 203 & 17 & 4 & 3 & 3 & 2 & 1 & 0 & 0 & $0-58$ & 9.2 & 7.46 & 251 \\
\hline & 2005 & & & & & & & & & & & & & & \\
\hline & Male & 0 & 7 & 10 & 12 & 18 & 25 & 127 & 61 & 36 & 12 & $4-68$ & 47.9 & 8.66 & 308 \\
\hline & Female & 30 & 201 & 40 & 12 & 2 & 2 & 0 & 0 & 0 & 0 & $0-42$ & 9.3 & 5.40 & 287 \\
\hline
\end{tabular}

standard deviation of 3.89 indicates that $95 \%$ of the female population produced 7.22 to 22.78 number of leaves per plant. In 2005, the number of leaves in the male population at 2 WAP ranged from 4 to 24 with a mean of 9.4 (Table 3). A standard deviation of 2.45 implies that $95 \%$ of the male population has between 2.9 and 12.7 number of leaves. In the female population, the number of leaves ranged from 6.0 to 27.0 with a mean of 16.3(Table 3). A standard deviation of 4.0 indicates that $95 \%$ of the females has between 8.3 and 24.3 number of leaves.
At 4 WAP in 2004, the number of leaves in the male population ranged from 10 to 38 with a mean of 19.7 (Table 3). A standard deviation of 6.63 indicates that $95 \%$ of the male population had between 6.44 and 32.96 leaves. In the female population, the number of leaves ranged from 17 to 90 with a mean of 47.8 (Table $3)$. A standard deviation of 13.46 indicates that $95 \%$ of the females had number of leaves that fell within the range of 20.88 and 74.72. The result of the number of leaves obtained at 4 WAP in 2005 were similar to that of 2004 in the male and female fluted pumpkin population. 
The trend was also consistent at 6 weeks after planting with mean number of leaves of 62.0 for the male and 105.6 for the females in 2004 (Table 3). In 2005, the female plants maintained the same tempo in leaf production as in 2004 with value of 116.4 at 6 weeks after planting in comparison with the value of 61.8 obtained from the male plants (Table 3 ).

The number of tendrils of the male and female fluted pumpkin was taken at 2, 4 and 6 weeks after planting (WAP) in 2004 and 2005. The results are presented in Table 4. At 2 WAP in 2004, the number of tendrils in the male population ranged from 0.0 to 13.0 with a mean of 5.7 (Table 4). A standard deviation of 2.18 indicates that $95 \%$ of the male population produced 1.34 to 10.06 tendrils per plant. In the female population, the number of tendrils ranged from 0.0 to 9.0 with a mean of 2.0 at 2 WAP in 2004 (Table 4). A standard deviation of 1.78 indicates that $95 \%$ of the female population has number of tendrils that fell within the range of 0.0 to 5.56. At $2 \mathrm{WAP}$, the distribution of the plants with respect to number of tendrils in the male and female populations in 2005 were similar to the results obtained in 2004 (Table 4).

At 4 WAP in 2004, the number of tendrils in the male population ranged from 0.0 to 30. 0 with a mean of 18.5 (Table 4). A standard deviation of 5.29 implies that $95 \%$ of the male population had number of tendrils that fell within the range of 7.92 and 29.08. In the female population the number of tendrils ranged from 0.0 to 24.0 with a mean of 4.3 (Table 4 ) A standard deviation of 3.29 indicates that $95 \%$ of the female population has number of tendrils that fell within the range of 0.0 to 10.88 . In 2005, the number of tendrils in the male population ranged from 2.0 to 27.0 with a mean of 16.2 (Table 4). A standard deviation of 5.82 indicates that $95 \%$ of the male population has between 4.56 and 27.84 tendrils per plant. In the female population, the number of tendrils ranged between 0.0 to 20.0 with a mean of 4.3 (Table 4). A standard deviation of 3.17 indicates that $95 \%$ of the female population has number of tendrils that ranged between 0.0 to 10.64 .

At 6 WAP in 2004, the number of tendrils in the male population ranged from 8.0 to 67.0 with a mean of 48.3 (Table 4). A standard deviation of 8.85 implies that $95 \%$ of the male population has number of tendrils that fell within the range of 30.6 and 66.0. In the female population the number of tendrils ranged from 0.0 to 58.0 with a mean of 9.2 (Table 4). A standard deviation of 7.46 shows that $95 \%$ of the female population has number of tendrils that fell within the range of 5.72 and 24.12. In 2005, the number of tendrils in the male population ranged from 4 to 68 with a mean of 47.9 at 6
WAP (Table 4). A standard deviation of 8.66 indicates that $95 \%$ of the male population has number of tendrils that fell within the range of 30.58 and 65.22 . In the female population, the number of tendrils ranged from 0.0 to 42.0 with a mean of 7.5 (Table 4). A standard deviation of 5.40 indicates that $95 \%$ of the female population has number of tendrils within the range of 0.0 to 18.3. There was no significant difference $(\mathrm{P}>0.05)$ between the male and female fluted pumpkin with respect to girth of vine.

\section{DISCUSSION}

The results on the weight of the seeds that grew into male and female fluted pumpkin and the number of days to shoot emergence revealed no significant difference between the male and female fluted pumpkin with respect to both characters. This suggests that gender had no effect on both traits.

The mean number of days to tendril emergence in the male plants differed significantly from those of the female plants. The male plants produced tendrils earlier than the female plants. The early and profused production of tendrils could provide a reliable guide for early identification and possible elimination of the male plants by farmers. The higher number of tendrils produced by the male fluted pumpkin contributed to the fibrous and unattractive nature of the males. The number of tendrils differed significantly $(\mathrm{P}<0.05)$ between both sexes in the first 6 weeks of growth. The profusion of tendrils in the male plants is one of the characteristics that confer the scrawny attribute of the male plants. The male plants were consistent in earliness and in higher number of tendrils produced over the female plants in both years. Both attributes are visible juvenile markers that can be relied upon for early detection of male plants by fluted pumpkin growers.

The frequency distribution of the female plants with respect to vine length showed skewness to the right in favour of the females as against the negative skewness in the male plants indicating that the females grew faster than the male plants from 14 days after planting. This is in contrast to earlier report (Emebiri and Nwufo 1996) that sex related differences in fluted pumpkin can be detected by 64 days after planting for length of vine.

The distribution of the male and female fluted pumpkin with respect to number of leaves from emergence to 6 weeks after planting (WAP) appears to suggest that the female plants were more prolific in leaf production than the male plants. Plants that partition a large portion of their photosynthates for leaf production during the early growth stage may grow at faster 
rate. Since the females produced more leaves, they grew faster than the males. As the female plants increased in size, they had larger meristematic region and with the presence of more leaves the plants were able to capture and utilize higher light energy that may have conferred a competitive advantage on the females. In contrast to the males, the female plants had luxuriant shoot growth as implicated by the longer vines and higher number of leaves throughout the early growth stage. Shoot length had been reported to have significant positive correlation with root dry matter in castor plant (Uguru, 2000) thereby suggesting that the growth of the aerial parts of the plant (shoot) had a direct bearing with the roots underground. By implication, the female fluted pumpkin with luxuriant shoot growth had better formed roots with perhaps higher nutrient mining power than the male. This may account for the consistent better performance of the female over the male plants. Ajibade (2004) attributed the vigorous growth of the female fluted pumpkin over the male counterpart to higher nutrients absorbed and utilized by the females. Ndukwu et al. (2005) revealed that the female fluted pumpkin was generally larger in size than the male in morphological features. Photosynthesis and dry matter production of a plant are proportional to the amount of leaf area developed (Purseglove 1977). This may provide an additional explanation why the females had faster growth rate than the males.

In both years, girth development at the early stage occurred at the same rate in both sexes. There was no significant difference $(\mathrm{P}>0.05)$ between the male and female fluted pumpkin with respect to girth of vine. The use of plant girth to differentiate the sexes at early growth stages is therefore not reliable.

The bulk of fluted pumpkin in tropical West Africa is mostly produced by subsistence peasant farmers with little or no education. Visible phenotypic appearances which are easily recognizable in fluted pumpkin will be better appreciated by this group of farmers. Time of tendril emergence and the number of tendrils are such visible phenotypic traits that can be appreciated by the farmers that grow fluted pumpkin. The observed phenotypic expression in the male and female fluted pumpkin at their juvenile growth stage revealed that the female had more vigorous growth rate and fewer tendrils in contrast to the males with less vigorous growth rate and more tendrils. At the juvenile stage, the females are identified by longer and robust vine, higher number of leaves and very few tendrils while the males are identified by shorter and thinner vines, less number of leaves and many tendrils. Of these characters, the two that can easily be observed and utilized by the uneducated farmers are earliness to tendril production and the number of tendrils produced. These are sex linked morphological markers in fluted pumpkin. The plants that are precocious and prolific in tendril production are male plants.

\section{REFERENCES}

Ajibade, S.R., Balogun, M.O., Afolabi, O.O., Kupolati, M.D. (2004). Sex Difference in Biochemical contents of Telfairia occidentalis Hook. F. Proceeding of the $30^{\text {th }}$ Annual conferences of the Genetics Society of Nigeria Held at University of Nigeria, Nsukka. $5^{\text {th }}-8^{\text {th }}$ September, 2005, 246-249.

Asiegbu, J.E. (1985). Characterization of Sexes in Fluted Pumpkin. growth and yield in the male and female sexes. Gartenbauwissenschaft Horticultural Science 50 (6): 251-255.

Emebiri, L.C., M.I. Nwufo (1996). Occurrence and Detection of Early Sex-related differences in Telfairia Occidentials. Journal of Sexual Plant Reproduction. $9(3): 140-144$

Esiaba, R.O. (1983). Cultivating Fluted Pumpkin in Nigeria. World Crops, March/April 70-72.

Gill, L.S. (1988). Taxonomy of flowering plants. Africana Fep Publisher Ltd, Ibadan 109 pp.

Irvine, F.R. (1969). West African Crops Oxford University Press $272 \mathrm{pp}$

Ndukwu, B.C., Obute G.C., Warg-Toby I. L. (2005). Tracking Sexual Dimorphison in Telfairia occidentalis Hook F. (Cuccubitaceae) with Morphological and Molecular markers. African Journal of Biotechnology 4 (11): 12451249.

Purseglove, J.W. (1977). Tropical Crops Dicotyledons (volumes 1 and 2 combined) Longman, London.

Rice, R. P., L.W. Rice, H.D. Tindall (1986). Fruit and Vegetable Production in Africa. Macmillan Press Ltd, London. 195-196 pp.

Satterthwaite, F.W. (1946), “An Approximate Distribution of Estimates of Variance Components", Biometrics Bulletin 2: 110-114.

Uguru, M.I. (2000), Genetic Variability and Breeding Value of Castor genotypes. Agro-Science 1 (1): 130-135

Uguru, M.I and Onovo, J.C. (2010) Gender in fluted pumpkin (Telfairia occidentalis Hook. F.) International Journal of Plant Breeding 4(1). (In Press) 